\title{
Novel Ethephon Application Methods for Narcissus
}

\author{
William B. Miller ${ }^{2}$ and Madeline W. Olberg ${ }^{1}$ \\ School of Integrative Plant Science, Section of Horticulture, 134A Plant \\ Science Building, Cornell University, Ithaca, NY 14853
}

Additional index words. daffodil, dutch bulbs, ethylene, plant growth regulators, temperature

\begin{abstract}
Ethephon [(2-chloroethyl) phosphonic acid] is a plant growth regulator (PGR) that releases ethylene following application. Although ethephon is commonly used as a foliar spray during the commercial production of ornamental crops, including spring bulb crops such as daffodil (Narcissus pseudonarcissus L.), there has been increased interest in using ethephon as a root-zone-applied PGR. In this work, we evaluated a number of factors important for the development of ethephon as a soil drench for daffodil. Results indicate that a given dose (milligrams ethephon per pot) could be applied in volumes ranging from 15 to $120 \mathrm{~mL}$ (per $15-\mathrm{cm}$ pot) with equal efficacy. Similarly, the same dose of ethephon could be applied as a foliar/substrate surface spray with volume of 105 to $525 \mathrm{~mL} \cdot \mathrm{m}^{-2}$ with equal efficacy. Although the efficacy of ethephon drenches interacted with forcing temperature, drenches were nonetheless effective across the range of temperatures commonly used for daffodil production. Plant size at the time of ethephon application had no effect on final plant size (at flower senescence). The rate of ethylene release from a peat-based substrate was highly temperature dependent, and ethephon was readily leached from this same substrate.
\end{abstract}

In the daffodil pot plant forcing industry, ethephon sprays have been the most common method of height control (de Hertogh, 1996), but they are not always effective (W.B. Miller, personal communication; Moe, 1980). In a previous paper (Miller et al., 2012), the potential of ethephon substrate drenches for height control in Narcissus was presented. For a wide range of cultivars, ethephon substrate drenches were effective in the range of 100 to 500 $\mathrm{mg} \cdot \mathrm{L}^{-1}$, (12 to $\left.60 \mathrm{mg} / \mathrm{pot}\right)$ when delivered in $120-\mathrm{mL}$ drench volume (which is a typical volume used for substrate drenches in floriculture for crops growing in $15-\mathrm{cm}$ pots).

For daffodil, unlike most other floriculture crops, growth control is needed more in the post-greenhouse retail and consumer phases than during commercial greenhouse production. This is because the optimum retail period is during the phase of rapid stem elongation, and therefore most daffodils are shipped from production greenhouses when they are only $1 / 3$ to $1 / 2$ of their final height.

For industry adoption, additional information on ethephon drench efficacy under different application scenarios is needed. For example, if a constant dose of ethephon is given, does drench volume alter the growth retarding effect? What effect does plant size at the time of treatment have on response to

Received for publication 14 July 2016. Accepted for publication 22 Aug. 2016.

We are especially grateful to Roselee Harmon, Kendra Hutchins, Amber van Dyken, Tim Klaver, and Roos de Wit for superior technical assistance. ${ }^{1}$ Undergraduate student. Current affiliation: Department of Horticulture, University of Wisconsin, Madison, WI.

${ }^{2}$ Corresponding author. E-mail: wbm8@cornell. edu. ethephon? How does greenhouse temperature influence efficacy of ethephon substrate drenches? How does substrate temperature affect ethylene evolution from ethephon in the root zone?

For this work, we chose three cultivars with dramatically different growth habits. The cultivars Primeur and Ice Follies are large flowered daffodils, with a single (usually) flower per stem, with 1-3 stems per bulb. Tete-a-Tete is a multistemmed and multiflowered cultivar that, even though compact when flowers first open, exhibits significant leaf and stem elongation during the postharvest phase. In addition to examining plant response, we also determined substrate temperature effects on ethylene release from ethephon and the extent of ethephon leaching from a peatbased substrate.

\section{Materials and Methods}

Expt. 1: Ethephon drench concentration and volume. On two dates, bulbs of Narcissus 'Primeur' and 'Tete-a-Tete' were planted into $15-\mathrm{cm}$ round plastic containers (three bulbs per container) using a soilless peat-based substrate (LM-111; Lambert Peat Moss, Inc., RiviereOuelle, Quebec, Canada). After thorough irrigation, bulbs were cooled for 16 weeks as described by Miller et al. (2012). After cooling, rooted bulbs were moved into a glass-glazed greenhouse (10 Feb. and 10 Mar., respectively) and grown at an average daily temperature (ADT) of $20.2{ }^{\circ} \mathrm{C}$ (calculated from $15 \mathrm{~min}$ datalogger readings; Onset Computer Corp., Bourne, MA).

Ethephon (Collate ${ }^{\mathrm{TM}}$; FineAmericas, Walnut Creek, CA) substrate drenches were applied when plants were 6- to $10-\mathrm{cm}$ tall, 2-3 h after bringing pots to container capacity with tap water. Treatments were $120,90,60,30$ and $15 \mathrm{~mL}$ of solution per pot containing 250 , 333, 500, 1000, and $2000 \mathrm{mg} \cdot \mathrm{L}^{-1}$ ethephon, respectively, each providing $30 \mathrm{mg}$ a.i. per pot, plus a nonethephon control (drenched with $120-\mathrm{mL}$ water). There were six replicate pots per treatment.

For all experiments, additional irrigation was withheld for $48 \mathrm{~h}$ after ethephon application. Data were collected on flower stalk (pot rim to top of flower, herein referred to as a "stem") and leaf length (from soil level to tip of leaf) on the first flower that opened per pot and on the tallest stem, and longest leaf (per pot) at the conclusion of flowering (defined as the point when $\approx 80 \%$ of the flowers per pot showed visible senescence). Growth increment $(\mathrm{cm})$ of each during the flowering period was obtained by subtraction.

Expt. 2: Ethephon spray concentration and volume. Bulbs were planted and handled as in Expt. 1. At the same growth stage as in Expt. 1, plants (and substrate surface, given that plants at this stage do not cover the surface of the substrate) were sprayed (per $\mathrm{m}^{2}$ ) with $105,210,315,420$, or $525 \mathrm{~mL}$ of 12,000 , $6000,4000,3000$, or $2400 \mathrm{mg} \cdot \mathrm{L}^{-1}$ ethephon (Collate); respectively, each treatment delivering $30 \mathrm{mg}$ ethephon a.i. per pot, plus a nonethephon control (sprayed with $210 \mathrm{~mL}$ water). All treatments contained a commercial surfactant (CapSil; Aquatrols, Paulsboro, NJ) at $0.5 \mathrm{~mL} \cdot \mathrm{L}^{-1}$. The dosage delivered per pot was calculated by considering the open surface area of the pot relative to the volume and total area sprayed. The two experiments (greenhouse dates of $10 \mathrm{Feb}$. and $10 \mathrm{Mar}$., respectively) each had six replicate pots per treatment. Greenhouse environmental conditions were the same as in Expt. 1.

Expt. 3: Timing of ethephon drenches on plant growth and development. Bulbs were planted and handled as in Expt. 1, with the exception that plants were removed from the cooler at 2-d ('Primeur', starting 20 Jan.) or 1-d ('Tete-a-Tete', starting 28 Jan.) intervals. Ultimately, plants had a total of 103 to $119 \mathrm{~d}$ ('Primeur') or 111 to $119 \mathrm{~d}$ of cold ('Tete-a-Tete'). In the repeat experiment, plants had 119 to 135 or 127 to 135 cold days ('Primeur' or 'Tete-a-Tete', respectively). Plants were treated with ethephon $(120-\mathrm{mL}$ substrate drench, at $250 \mathrm{mg} \cdot \mathrm{L}^{-1}$, providing $30 \mathrm{mg}$ a.i. per pot using Collate) on the date the last plants came out of the cooler (5 Feb. and 13 Mar. for the first and second experiments, respectively). Thus, at the time of ethephon treatment, plants had been in the greenhouse for 0 to $16 \mathrm{~d}$ ('Primeur') or 0 to $8 \mathrm{~d}$ ('Tete-a-Tete') and had large differences in leaf and stem length between treatments. There were four replicate pots per treatment. Greenhouse environmental conditions were the same as in Expt. 1.

Expt. 4: Effect of growing temperature on efficacy of ethephon substrate drenches. Bulbs were planted and handled as in Expt. 1, with a total cooling duration of 17 weeks. Plants were initially grown at a common ADT of $20.2{ }^{\circ} \mathrm{C}$. One day before ethephon application (at the growth stage identified in Expt. 1), plants were moved into one of four greenhouse 
temperatures: $15,17.5,20$, or $23^{\circ} \mathrm{C}$, where they remained for the duration of the experiment. One day following transfer to the new temperatures, plants were drenched with $120 \mathrm{~mL}$ of $250 \mathrm{mg} \cdot \mathrm{L}^{-1}$ ethephon $(30 \mathrm{mg}$ a.i. per pot; Collate). There were eight replicate pots per treatment for cultivars Ice Follies and Tete-a-Tete and four pots per treatment for 'Primeur'.

Expt. 5: Effect of temperature on the release of ethylene from ethephon in planting mix. Pint glass jars were partially filled with $400 \mathrm{~mL}$ of moistened soilless peat-based substrate (LM-111), and then distributed randomly to one of eight temperature environments (in controlled temperature cabinets or water baths): $1,4,9,13,17,20,23$, or $28^{\circ} \mathrm{C}$ (each averaging within $0.3{ }^{\circ} \mathrm{C}$ of the set point, based on $15 \mathrm{~min}$ datalogger readings, as above). There were six replicate jars per temperature. The following day, each jar received $40 \mathrm{~mL}$ of $125 \mathrm{mg} \cdot \mathrm{L}^{-1}$ ethephon (5 mg a.i. per jar; Collate). Additional jars were prepared without substrate and contained ethephon as used above with one pellet of $\mathrm{KOH}$ (added to release all ethylene from the ethephon). Jars were sealed with a lid fitted with a septum. Over the following $9 \mathrm{~d}$, ethylene evolution was determined by gas chromatography (GC) of a 1-mL headspace sample. It was assumed that evolved ethylene was not adsorbed by the substrate and that the entire sealed volume was available to the ethylene.
Expt. 6: Leaching of ethephon from soilless media. Ten-centimeter pots were filled with LM-111, brought to container capacity with RO water, then irrigated with $100 \mathrm{~mL}$ of $500 \mathrm{mg} \cdot \mathrm{L}^{-1}$ (50 mg a.i.) ethephon (Florel; Monterey Lawn and Garden Products, Fresno, CA). Four replicate pots each were leached with 100 to $500 \mathrm{~mL}$ reverse osmosis water in $100-\mathrm{mL}$ aliquots. A $25-\mathrm{mL}$ subsample of leachate resulting from each aliquot was transferred to a 50-mL erlenmeyer flask, and one pellet of $\mathrm{KOH}$ was added to release ethylene. Flasks were sealed with a septum, and the ethylene accumulated after $24 \mathrm{~h}$ was measured by GC. After leaching, pots with substrate were sealed into 1.9-L vessels and ethylene emanating from the substrate was accumulated in the headspace for $24 \mathrm{~h}$ and analyzed by GC.

\section{Results}

Expt. 1: Ethephon drench concentration and volume. Ethephon was applied in a range of volumes and concentrations, each delivering $30 \mathrm{mg}$ a.i. per pot. Compared with untreated controls, ethephon drenches reduced stem and leaf length at the end of flowering and generally reduced the growth increment (elongation) between first flower and the end of flower (Table 1). At the first flower stage, ethephon treatments reduced stem, and leaf length with 'Primeur', but less so for 'Tete-a-Tete'. In nearly all cases, there was no difference in stem or leaf length at the end of flowering between the various ethephon drench volume and concentration treatments (Table 1), but all were significantly different from the nontreated controls.

Expt. 2: Ethephon spray concentration and volume. Similar to the above experiment, spray treatments delivering $30 \mathrm{mg}$ a.i. per pot but widely differing in spray volume applied, were not significantly different from each other, but were, in nearly all cases, significantly shorter than untreated control plants (Table 2).

Expt. 3: Timing of ethephon drenches on plant growth and development. As expected, plant size at the time of ethephon application was directly related to length of time plants had been in the greenhouse (Figs. 1 and 2). For both cultivars, ethephon substrate drenches significantly reduced plant height at the end of flowering (Figs. 1 and 2), and in most cases, the age and size of plants at the moment of ethephon application had no effect on final stem or leaf length. Plants given ethephon substrate drenches when very small (soon after bringing them into the greenhouse) grew significantly more after ethephon treatment than did plants given ethephon when they were larger, but stems and leaves of all ethephon-treated plants were the same length at the conclusion of flowering. There was no effect of treatment date on the number of flowering stems for 'Primeur' and averaged

Table 1. Effect of ethephon drench volume and concentration (each delivering 30-mg ethephon a.i. per pot) on Narcissus growth and development. Stem and leaf growth increment refers to the difference between the lengths at first flower and the end of flowering.

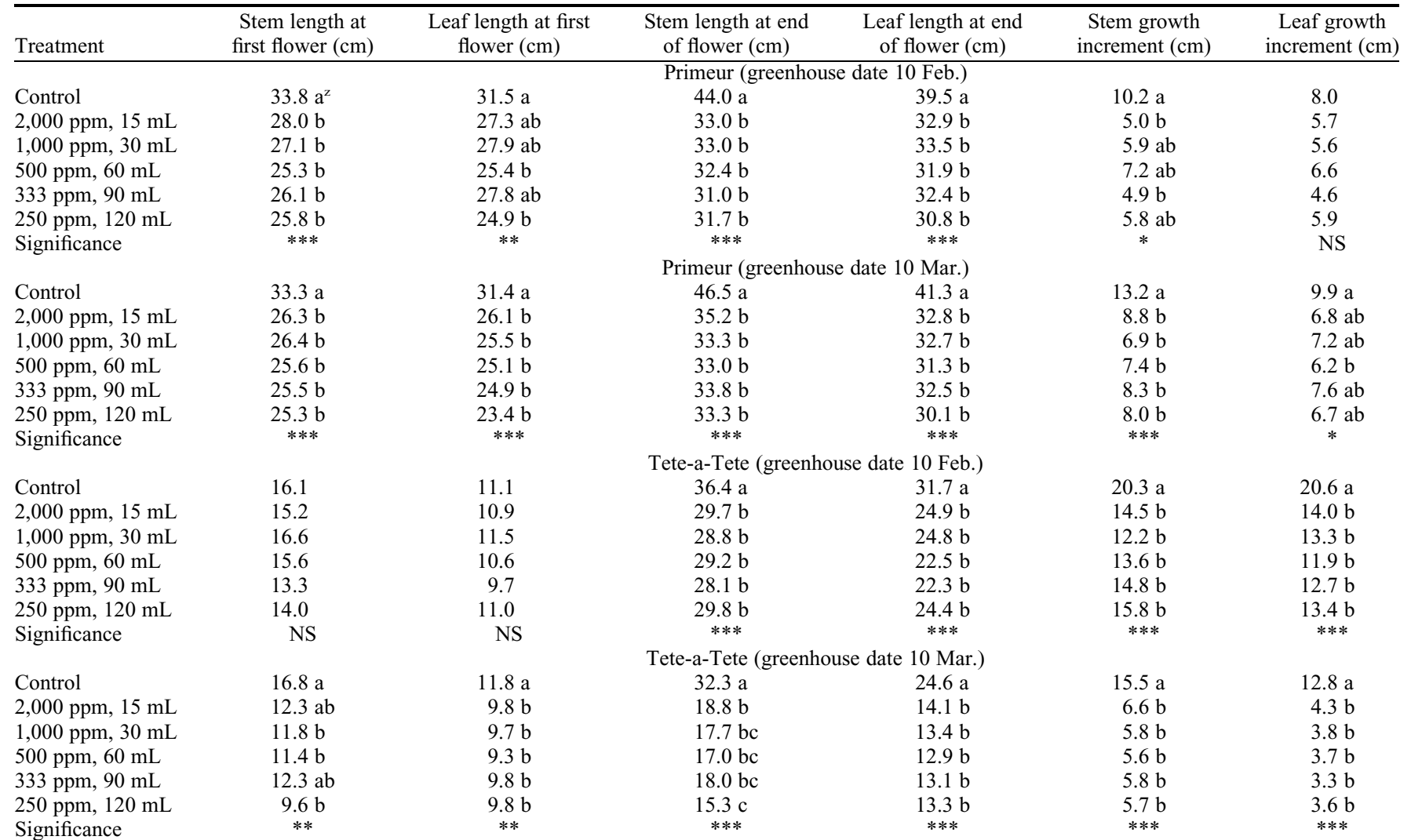

${ }^{\mathrm{z}}$ Means (within cultivar and experiment) followed by different letters are significantly different at the $5 \%$ level, using Tukey-Kramer honestly significant difference. Means without letters are not significantly different.

NS, ${ }^{*},{ }^{* *},{ }^{* * *}$ Nonsignificant or significant at $P \leq 0.05,0.01$, or 0.001 , respectively. 
Table 2. Effect of ethephon spray volume and concentration (each treatment nominally delivering $30 \mathrm{mg}$ a.i. per pot) on Narcissus growth and development. Stem and leaf growth increment refers to the difference between the lengths at first flower and the end of flowering.

\begin{tabular}{|c|c|c|c|c|c|c|}
\hline Treatment & $\begin{array}{l}\text { Stem length at } \\
\text { first flower }(\mathrm{cm})\end{array}$ & $\begin{array}{l}\text { Leaf length at } \\
\text { first flower }(\mathrm{cm})\end{array}$ & $\begin{array}{l}\text { Stem length at end } \\
\text { of flower }(\mathrm{cm})\end{array}$ & $\begin{array}{l}\text { Leaf length at end } \\
\text { of flower }(\mathrm{cm})\end{array}$ & $\begin{array}{l}\text { Stem growth } \\
\text { increment }(\mathrm{cm})\end{array}$ & $\begin{array}{l}\text { Leaf growth } \\
\text { increment }(\mathrm{cm})\end{array}$ \\
\hline Control & $37.2 \mathrm{a}^{\mathrm{z}}$ & 32.3 & $44.3 \mathrm{a}$ & $39.0 \mathrm{a}$ & 7.2 & 6.8 \\
\hline $105 \mathrm{~mL} \cdot \mathrm{m}^{-2}, 12,000 \mathrm{ppm}$ & $31.0 \mathrm{~b}$ & 30.0 & $37.0 \mathrm{~b}$ & $35.1 \mathrm{ab}$ & 6.0 & 5.1 \\
\hline $315 \mathrm{~mL} \cdot \mathrm{m}^{-2}, 4,000 \mathrm{ppm}$ & $28.5 \mathrm{~b}$ & 28.5 & $35.3 \mathrm{bc}$ & $33.4 \mathrm{~b}$ & 6.8 & 4.9 \\
\hline $420 \mathrm{~mL} \cdot \mathrm{m}^{-2}, 3,000 \mathrm{ppm}$ & $28.4 \mathrm{~b}$ & 28.1 & $34.8 \mathrm{bc}$ & $33.9 \mathrm{~b}$ & 6.3 & 5.8 \\
\hline $525 \mathrm{~mL} \cdot \mathrm{m}^{-2}, 2,400 \mathrm{ppm}$ & $28.2 \mathrm{~b}$ & 29.6 & $33.3 \mathrm{c}$ & $34.7 \mathrm{ab}$ & 5.2 & 5.1 \\
\hline Control & $33.2 \mathrm{a}$ & $30.7 \mathrm{a}$ & $46.3 \mathrm{a}$ & $40.8 \mathrm{a}$ & $13.1 \mathrm{a}$ & $10.2 \mathrm{a}$ \\
\hline $105 \mathrm{~mL} \cdot \mathrm{m}^{-2}, 12,000 \mathrm{ppm}$ & $25.2 \mathrm{~b}$ & $26.0 \mathrm{~b}$ & $35.0 \mathrm{~b}$ & $34.8 \mathrm{~b}$ & $9.8 \mathrm{~b}$ & $8.8 \mathrm{ab}$ \\
\hline $210 \mathrm{~mL} \cdot \mathrm{m}^{-2}, 6,000 \mathrm{ppm}$ & $25.8 \mathrm{~b}$ & $26.3 \mathrm{~b}$ & $34.2 \mathrm{~b}$ & $32.8 \mathrm{~b}$ & $8.4 \mathrm{~b}$ & $6.6 \mathrm{~b}$ \\
\hline $315 \mathrm{~mL} \cdot \mathrm{m}^{-2}, 4,000 \mathrm{ppm}$ & $26.2 \mathrm{~b}$ & $26.8 \mathrm{~b}$ & $35.1 \mathrm{~b}$ & $35.3 \mathrm{~b}$ & $8.9 \mathrm{~b}$ & $8.6 \mathrm{ab}$ \\
\hline $420 \mathrm{~mL} \cdot \mathrm{m}^{-2}, 3,000 \mathrm{ppm}$ & $24.9 \mathrm{~b}$ & $25.5 \mathrm{~b}$ & $34.0 \mathrm{~b}$ & $32.4 \mathrm{~b}$ & $9.1 \mathrm{~b}$ & $6.9 \mathrm{~b}$ \\
\hline $525 \mathrm{~mL} \cdot \mathrm{m}^{-2}, 2,400 \mathrm{ppm}$ & $25.8 \mathrm{~b}$ & $26.3 \mathrm{~b}$ & $34.8 \mathrm{~b}$ & $33.6 \mathrm{~b}$ & $9.0 \mathrm{~b}$ & $7.3 \mathrm{~b}$ \\
\hline Significance & $* * *$ & ** & $* * *$ & $* * *$ & $* * *$ & $* *$ \\
\hline $420 \mathrm{~mL} \cdot \mathrm{m}^{-2}, 3,000 \mathrm{ppm}$ & $12.6 \mathrm{~b}$ & 10.5 & $29.9 \mathrm{~b}$ & $24.2 \mathrm{~b}$ & $17.3 \mathrm{ab}$ & 13.7 \\
\hline $525 \mathrm{~mL} \cdot \mathrm{m}^{-2}, 2,400 \mathrm{ppm}$ & $12.6 \mathrm{~b}$ & 10.3 & $28.7 \mathrm{~b}$ & $26.3 \mathrm{ab}$ & $16.1 \mathrm{~b}$ & 15.9 \\
\hline Significance & $* * *$ & NS & $* * *$ & $* *$ & * & NS \\
\hline & \multicolumn{6}{|c|}{ Tete-a-Tete (greenhouse date 10 Mar.) } \\
\hline Control & $18.3 \mathrm{a}$ & 11.1 & $32.6 \mathrm{a}$ & $24.0 \mathrm{a}$ & $14.3 \mathrm{a}$ & $12.9 \mathrm{a}$ \\
\hline $105 \mathrm{~mL} \cdot \mathrm{m}^{-2}, 12,000 \mathrm{ppm}$ & $12.5 \mathrm{~b}$ & 9.9 & $19.9 \mathrm{~b}$ & $15.4 \mathrm{~b}$ & $7.4 \mathrm{~b}$ & $5.5 \mathrm{~b}$ \\
\hline $210 \mathrm{~mL} \cdot \mathrm{m}^{-2}, 6,000 \mathrm{ppm}$ & $11.1 \mathrm{~b}$ & 9.6 & $16.4 \mathrm{~b}$ & $13.7 \mathrm{~b}$ & $5.3 \mathrm{~b}$ & $4.1 \mathrm{~b}$ \\
\hline $315 \mathrm{~mL} \cdot \mathrm{m}^{-2}, 4,000 \mathrm{ppm}$ & $12.2 \mathrm{~b}$ & 9.7 & $19.2 \mathrm{~b}$ & $14.7 \mathrm{~b}$ & $7.0 \mathrm{~b}$ & $5.0 \mathrm{~b}$ \\
\hline $420 \mathrm{~mL} \cdot \mathrm{m}^{-2}, 3,000 \mathrm{ppm}$ & $11.4 \mathrm{~b}$ & 9.1 & $18.9 \mathrm{~b}$ & $15.2 \mathrm{~b}$ & $7.4 \mathrm{~b}$ & $6.1 \mathrm{~b}$ \\
\hline $525 \mathrm{~mL} \cdot \mathrm{m}^{-2}, 2,400 \mathrm{ppm}$ & $11.8 \mathrm{~b}$ & 9.6 & $19.5 \mathrm{~b}$ & $15.1 \mathrm{~b}$ & $7.8 \mathrm{~b}$ & $5.5 \mathrm{~b}$ \\
\hline Significance & $* * *$ & NS & $* * *$ & $* * *$ & $* * *$ & $* * *$ \\
\hline
\end{tabular}

${ }^{\mathrm{z}}$ Means (within cultivar and experiment) followed by different letters are significantly different at the $5 \%$ level, using Tukey-Kramer honestly significant difference. Means without letters are not significantly different.

NS, ${ }^{*},{ }^{* *}, * * *$ Nonsignificant or significant at $P \leq 0.05,0.01$, or 0.001 , respectively.

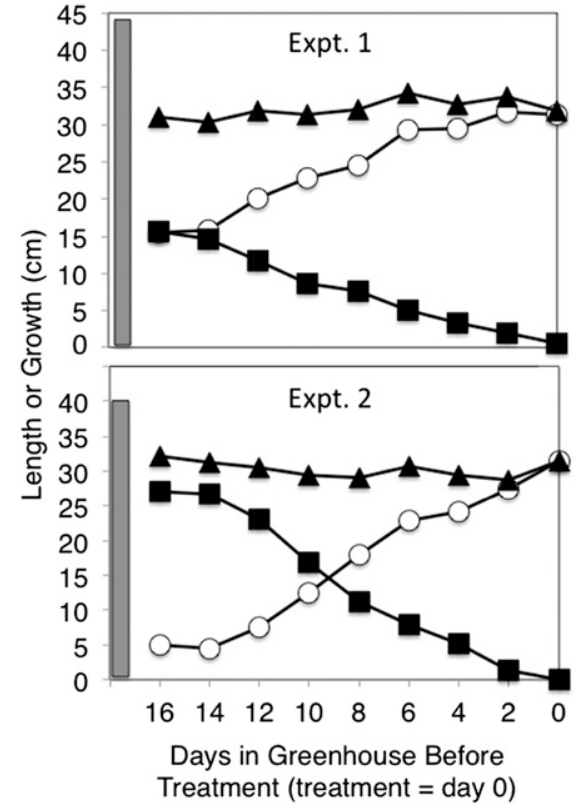

Fig. 1. Effect of plant size at time of root-zone ethephon application (squares) on final stem height (triangles) and growth increment from treatment to end of flowering (circles) for Narcissus 'Primeur'. Final height of untreated control plants is indicated by the gray bar in each panel. Plants were brought into the greenhouse on 28 Jan. (top) or 5 Mar. (bottom). Standard error bars are not indicated, but most fall within the size of the plotting symbol.
2.7 and 2.8 for Expts. 1 and 2, respectively. For 'Tete-a-Tete' entering the greenhouse on the later date, plants treated with ethephon drenches at a very early age tended to show a reduction in the number of normally developing flower stems (Table 3 ).

Expt. 4: Effect of growing temperature on efficacy of ethephon substrate drenches. For all three cultivars, growing temperature interacted with ethephon application to affect final stem length and stem growth increment from first flower to end of flowering (Table 4). Although the main effect of temperature was not significant for 'Ice Fillies' and 'Primeur', it was for 'Tete-a-Tete', and ethephon was highly significant in all three.

Final leaf length was only affected by ethephon application ('Ice Follies' and Primeur') or by both ethephon and temperature ('Tete-a-Tete'). The growth increment of the leaves was influenced only by ethephon, the main effect of temperature and the interaction with ethephon were all nonsignificant (Table 4).

Expt. 5: Effect of temperature on the release of ethylene from ethephon in peat-based mix. Assuming the ideal gas law, the theoretical ethylene concentration realized from $5 \mathrm{mg}$ $(34.6 \mu \mathrm{mol})$ of ethephon in our system was $1,650 \mu \mathrm{L} \cdot \mathrm{L}^{-1}$. The ethephon $+\mathrm{KOH}$ control released ethylene very close to this amount, $1,425 \mu \mathrm{L} \cdot \mathrm{L}^{-1}$ (Fig. 3). When ethephon was added to LM-111 planting mix and incubated at $28{ }^{\circ} \mathrm{C}$, essentially all ethephon was converted to ethylene within $9 \mathrm{~d}$, with less ethylene released as temperature decreased to $1{ }^{\circ} \mathrm{C}$ (Fig. 3). Table 5 shows the slopes of ethylene accumulation for the first $3 \mathrm{~d}$, during which there was a linear increase in ethylene accumulation for all temperatures. Over the first $3 \mathrm{~d}$, ethylene accumulation at $4{ }^{\circ} \mathrm{C}$ was $9.3 \%$ of the rate at $17{ }^{\circ} \mathrm{C}$ and the rate of ethylene accumulation was 2.5 -fold greater at $23{ }^{\circ} \mathrm{C}$ than at $17^{\circ} \mathrm{C}$. Figure 4 shows the relative accumulation after $9 \mathrm{~d}$. It is notable that from 13 to $23{ }^{\circ} \mathrm{C}$, which encompasses the range of typical Narcissus forcing, ethephon degradation in this peat-based substrate is essentially linear with respect to temperature (Fig. 4).

Expt. 6: Leaching of ethephon from peatbased media. Ethephon was readily leached from the peat-based soilless substrate (Fig. 5). The pots used in the experiment had a volume of $\approx 325 \mathrm{~mL}$. With a $500-\mathrm{mL}$ (total) leaching volume, the first $100 \mathrm{~mL}$ contained $\approx 42 \%$ of the leached ethephon, whereas the leachate from the 400- and 500$\mathrm{mL}$ aliquots contained only about $7 \%$ of the leached ethephon. After leaching, pots were placed in a sealed container, and ethylene was allowed to diffuse from the substrate. Although the amount of ethylene released from the substrate was dramatically reduced by leaching, some ethylene still was released from the substrate (Fig. 6). 


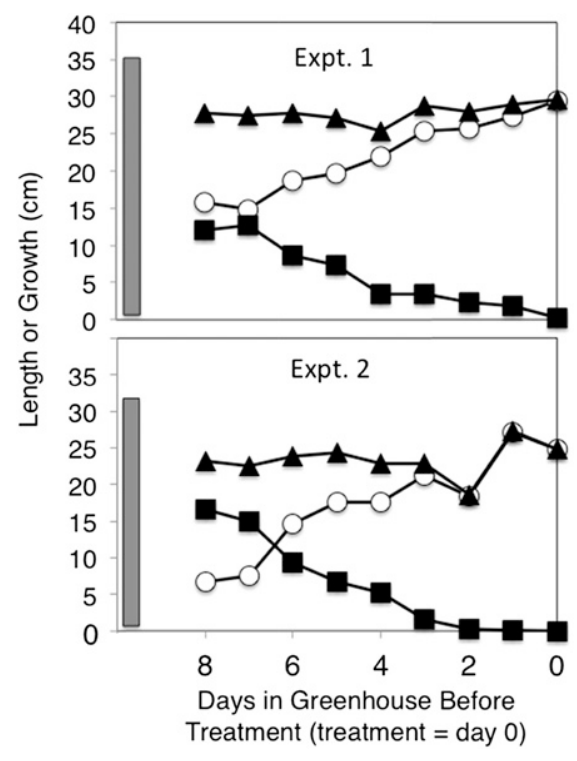

Fig. 2. Effect of plant size at time of root-zone ethephon application (squares) on final stem height (triangles) and growth increment from treatment to end of flowering (circles) for Narcissus 'Tete-a-Tete'. Final height of untreated control plants is indicated by the gray bar in each panel. Plants were brought into the greenhouse on 28 Jan. (top) or 5 Mar. (bottom). Standard error bars are not indicated, but most fall within the size of the plotting symbol.

Table 3. Effect of timing of ethephon substrate drench $(30 \mathrm{mg}$ a.i. per pot, delivered in $120 \mathrm{~mL}$ ) on number of flowering stems for 'Tete-a-Tete' Narcissus. Plants were brought into the greenhouse at the indicated intervals; ethephon was applied to plants on day 0 . Two independent experiments are indicated.

Number of days

plants were in

greenhouse before No. flowering stems per pot $\begin{array}{lll}\text { ethephon application } & \text { Expt. } 1 & \text { Expt. } 2\end{array}$

\begin{tabular}{lrl}
\hline Control (8 d) & 8.0 & $8.3 \mathrm{ab}^{\mathrm{z}}$ \\
8 & 10.5 & $8.8 \mathrm{a}$ \\
7 & 9.3 & $6.8 \mathrm{abc}$ \\
6 & 10.0 & $4.5 \mathrm{abc}$ \\
5 & 9.0 & $4.3 \mathrm{bc}$ \\
4 & 8.3 & $3.3 \mathrm{c}$ \\
3 & 9.0 & $4.0 \mathrm{bc}$ \\
2 & 6.8 & $2.5 \mathrm{c}$ \\
1 & 9.3 & $6.3 \mathrm{abc}$ \\
0 & 7.5 & $4.3 \mathrm{bc}$ \\
Significance & $\mathrm{NS}$ & $* * *$ \\
\hline
\end{tabular}

${ }^{\mathrm{z}}$ Means in a column followed by different letters are significantly different at the $5 \%$ level, using Tukey-Kramer honestly significant difference. Means without letters are not significantly different.

NS, ${ }^{* * *}$ Nonsignificant or significant at $P \leq 0.001$, respectively

\section{Discussion}

The present data show that dosage of ethephon (mg a.i./pot), and not the specific application method, is key in determining growth-regulating response. A given dose of ethephon, for example $30 \mathrm{mg}$ a.i., could be delivered as a substrate drench of 15 to $120 \mathrm{~mL}$ (with correspondingly different

Table 4. Effect of temperature on efficacy of ethephon substrate drenches $(30 \mathrm{mg}$ a.i. per pot, delivered in $120 \mathrm{~mL}$ ) on stem and leaf length and number of flowering stems at the end of flowering for three Narcissus cultivars. Plants were brought into the greenhouse on the indicated dates. Means of eight plants per treatment are presented (four pots per treatment for 'Primeur').

\begin{tabular}{|c|c|c|c|c|c|}
\hline \multirow[b]{2}{*}{ Temp $\left({ }^{\circ} \mathrm{C}\right)$} & \multirow[b]{2}{*}{ Ethephon } & \multicolumn{2}{|c|}{$\begin{array}{l}\text { Length at end of } \\
\text { flowering }(\mathrm{cm})\end{array}$} & \multicolumn{2}{|c|}{$\begin{array}{l}\text { Growth increment from first } \\
\text { flower to end of flowering }(\mathrm{cm})\end{array}$} \\
\hline & & Stem & Leaf & Stem & Leaf \\
\hline \multicolumn{6}{|c|}{ Ice Follies } \\
\hline No & 14.8 & $42.1 \mathrm{~b}^{\mathrm{z}}$ & $32.5 \mathrm{bc}$ & $10.8 \mathrm{ab}$ & $4.1 \mathrm{bc}$ \\
\hline No & 17.5 & $44.3 \mathrm{ab}$ & $34.9 \mathrm{ab}$ & $13.5 \mathrm{a}$ & $6.6 \mathrm{ab}$ \\
\hline No & 19.8 & $46.4 \mathrm{a}$ & $37.5 \mathrm{ab}$ & $12.3 \mathrm{a}$ & $8.9 \mathrm{a}$ \\
\hline No & 22.9 & $44.0 \mathrm{ab}$ & $35.1 \mathrm{ab}$ & $11.3 \mathrm{ab}$ & $5.5 \mathrm{abc}$ \\
\hline Yes & 14.8 & $36.1 \mathrm{c}$ & $27.8 \mathrm{~d}$ & $8.3 \mathrm{~b}$ & $2.2 \mathrm{c}$ \\
\hline Yes & 17.5 & $35.9 \mathrm{c}$ & $29.4 \mathrm{~cd}$ & $7.8 \mathrm{~b}$ & $3.2 \mathrm{bc}$ \\
\hline Yes & 19.8 & $33.8 \mathrm{~cd}$ & $30.1 \mathrm{~cd}$ & $7.8 \mathrm{~b}$ & $6.1 \mathrm{ab}$ \\
\hline Yes & 22.9 & $31.8 \mathrm{~d}$ & $27.8 \mathrm{~d}$ & $3.8 \mathrm{c}$ & $3.3 \mathrm{bc}$ \\
\hline Ethephon (E) & & $* * *$ & *** & $* * *$ & $* * *$ \\
\hline Temperature (T) & & NS & NS & $*$ & NS \\
\hline $\mathrm{E} \times \mathrm{T}$ & & $* * *$ & NS & * & NS \\
\hline \multicolumn{6}{|c|}{ Primeur } \\
\hline No & 14.8 & $37.0 \mathrm{~b}$ & $28.3 \mathrm{abc}$ & $7.0 \mathrm{abc}$ & $4.0 \mathrm{ab}$ \\
\hline No & 17.5 & $40.5 \mathrm{ab}$ & $32.4 \mathrm{a}$ & $9.0 \mathrm{ab}$ & $5.6 \mathrm{a}$ \\
\hline No & 19.8 & $42.9 \mathrm{a}$ & $33.8 \mathrm{a}$ & $10.3 \mathrm{a}$ & $6.1 \mathrm{a}$ \\
\hline No & 22.9 & $40.6 \mathrm{ab}$ & $29.9 \mathrm{ab}$ & $9.4 \mathrm{a}$ & $5.9 \mathrm{a}$ \\
\hline Yes & 14.8 & $29.1 \mathrm{c}$ & $21.8 \mathrm{~d}$ & $5.0 \mathrm{abc}$ & $2.5 \mathrm{ab}$ \\
\hline Yes & 17.5 & $31.1 \mathrm{c}$ & $24.5 \mathrm{bcd}$ & $5.0 \mathrm{abc}$ & $3.5 \mathrm{ab}$ \\
\hline Yes & 19.8 & $29.5 \mathrm{c}$ & $25.4 \mathrm{bcd}$ & $4.9 \mathrm{bc}$ & $4.1 \mathrm{ab}$ \\
\hline Yes & 22.9 & $29.3 \mathrm{c}$ & $22.8 \mathrm{~cd}$ & $2.9 \mathrm{c}$ & $2.0 \mathrm{~b}$ \\
\hline Ethephon (E) & & $* * *$ & $* * *$ & $* * *$ & $* *$ \\
\hline Temperature (T) & & NS & NS & NS & NS \\
\hline $\mathrm{E} \times \mathrm{T}$ & & $*$ & NS & $*$ & NS \\
\hline \multicolumn{6}{|c|}{ Tete-a-Tete } \\
\hline No & 14.8 & $28.7 \mathrm{bc}$ & $22.5 \mathrm{abc}$ & $9.8 \mathrm{bc}$ & $11.1 \mathrm{abc}$ \\
\hline No & 17.5 & $30.9 \mathrm{ab}$ & $23.1 \mathrm{abc}$ & $10.0 \mathrm{bc}$ & 9.9 bc \\
\hline No & 19.8 & $33.9 \mathrm{a}$ & $27.5 \mathrm{a}$ & $10.0 \mathrm{bc}$ & $14.7 \mathrm{a}$ \\
\hline No & 22.9 & $32.9 \mathrm{a}$ & $25.8 \mathrm{ab}$ & $10.7 \mathrm{ab}$ & $12.1 \mathrm{ab}$ \\
\hline Yes & 14.8 & $24.6 \mathrm{~d}$ & $20.1 \mathrm{c}$ & $6.4 \mathrm{~cd}$ & $9.3 \mathrm{bc}$ \\
\hline Yes & 17.5 & $25.6 \mathrm{~cd}$ & $20.3 \mathrm{c}$ & $6.6 \mathrm{~cd}$ & $7.1 \mathrm{c}$ \\
\hline Yes & 19.8 & $25.6 \mathrm{~cd}$ & $21.4 \mathrm{bc}$ & $5.1 \mathrm{~d}$ & $8.8 \mathrm{bc}$ \\
\hline Yes & 22.9 & $24.8 \mathrm{~cd}$ & $22.5 \mathrm{abc}$ & $3.5 \mathrm{~d}$ & $10.1 \mathrm{abc}$ \\
\hline Ethephon (E) & & $* * *$ & *** & $* * *$ & $* * *$ \\
\hline Temperature (T) & & $* *$ & ** & NS & NS \\
\hline $\mathrm{E} \times \mathrm{T}$ & & $*$ & NS & $*$ & NS \\
\hline
\end{tabular}

${ }^{\mathrm{z}}$ Means within cultivar and forcing date followed by different letters are significantly different at the $5 \%$ level, using Tukey-Kramer honestly significant difference.

Ns, *, **, *** Nonsignificant or significant at $P \leq 0.05,0.01$, or 0.001 , respectively.

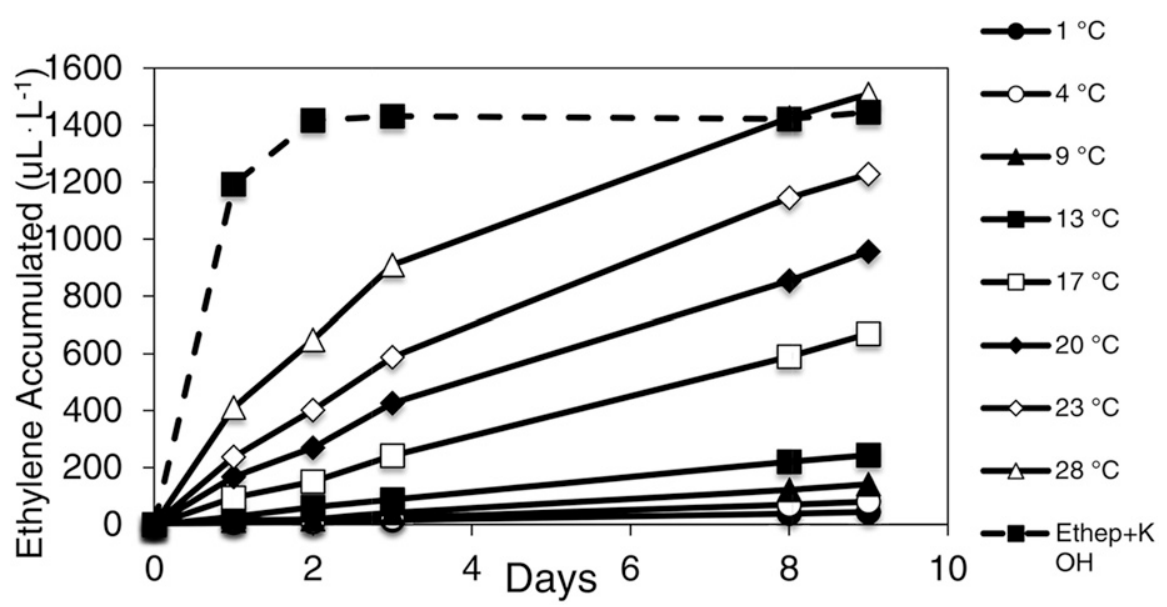

Fig. 3. Effect of temperature on ethylene evolution from ethephon in a commercial peat-based planting mix The ethephon $+\mathrm{KOH}$ control shows the maximum ethylene attained in the experiment, which was similar to the calculated maximum ethylene accumulation of $1650 \mu \mathrm{L} \cdot \mathrm{L}^{-1}$.

concentrations) with identical effects on plant growth. It is conceivable that even higher volumes could be used, but this would not be practically useful. Spray volumes varying from
105 to $525 \mathrm{~mL} \cdot \mathrm{m}^{-2}$ with concentrations adjusted to deliver $30 \mathrm{mg}$ a.i. per pot also give identical results. Thus, commercial growers would have options to use this product across 
Table 5. Effect of temperature on ethylene release from ethephon in a peat-based planting mix. Data are slopes of ethylene release for days $0-3$, derived from Fig. 3.

\begin{tabular}{ccc}
\hline & $\begin{array}{c}\text { Slope } \\
\text { Temp }\left({ }^{\circ} \mathrm{C}\right)\end{array}$ & $\begin{array}{c}\text { Slope } \\
\left(\mu \mathrm{L} \cdot \mathrm{L}^{-1} \cdot \mathrm{d}^{-1}\right)\end{array}$ \\
\hline 1 & 4.7 & 6.0 \\
4 & 7.7 & 9.3 \\
7 & 12.7 & 16.3 \\
13 & 29.6 & 37.9 \\
17 & 77.2 & 100 \\
20 & 137.9 & 176.4 \\
23 & 192.7 & 246.5 \\
28 & 296.4 & 379.1 \\
\hline
\end{tabular}

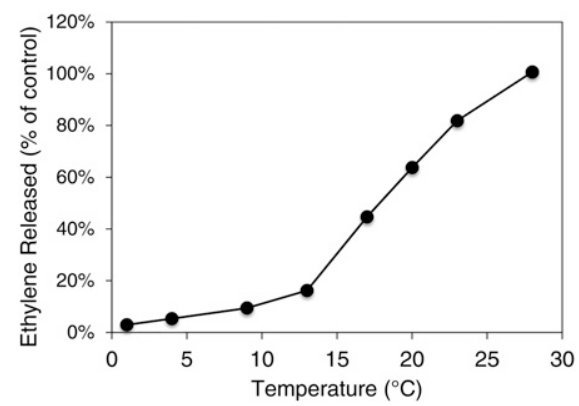

Fig. 4. Effect of temperature on ethylene release from ethephon in a commercial peat-based potting mix. Data points are means of ethylene accumulated after 9 d (Fig. 3) and expressed relative to ethylene released from an equal amount of ethephon with one pellet of $\mathrm{KOH}$ added to initiate ethylene release.

a wide range of application volumes spanning from a "heavy spray" to a traditional drench and get consistent and predictable results. This will be especially useful for producers with automated overhead traveling boom systems.

Although there was a significant interaction of growing temperature with substrate ethephon application, plants did respond significantly to ethephon across the range of growing temperatures in this experiment. Temperature had a profound effect on the rate of ethylene evolution from substrate in the peat-based media we used (Figs. 3 and 4). Previous studies have also described the marked effect of temperature on ethylene evolution from ethephon applied to tomato fruit and sour cherry leaves (Flore and Bukovac, 1982; Lougheed and Franklin, 1972; Olien and Bukovac, 1978) and from pure ethephon solutions buffered to pH 6.0 (Olien and Bukovac, 1978). Warmer temperatures tended to cause taller plants and as growth temperatures increased, the effect of substrate-applied ethephon also tended to increase. There could be several reasons for a larger effect at warmer temperatures. One could be an increased rate of conversion to ethylene at the warmer temperature, for example, there is $\approx 4.7$-fold increase in the rate of ethylene evolution at $20{ }^{\circ} \mathrm{C}$ vs. $13{ }^{\circ} \mathrm{C}$ (Table 5). Another could be increased plant sensitivity to ethylene at warmer temperatures. We cannot distinguish between these now, as we do not have a clear understanding of the mechanism of root-zone

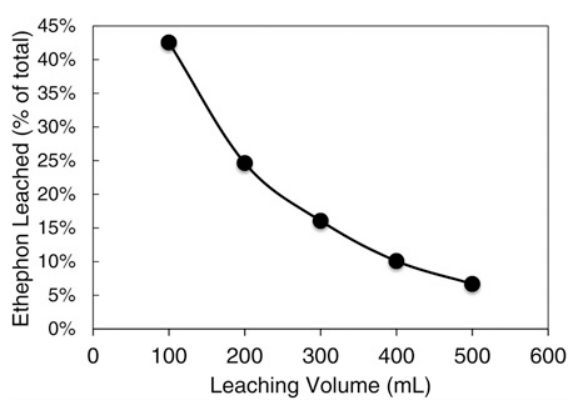

Fig. 5. Leaching of ethephon from a soilless peatbased potting mix. Pots of $10 \mathrm{~cm}$ were filled with Lambert LM-111, moistened, and then irrigated with $50-\mathrm{mg}$ ethephon in a $100-\mathrm{mL}$ volume. Pots were then leached with 100 to $500 \mathrm{~mL}$ water, in $100 \mathrm{~mL}$ aliquots, and ethylene concentration was determined in the leachate. Symbols are means of four replicates, and most standard errors are within the dimensions of the symbols used in the graph. Regression equation: $y=2 \mathrm{E}-06 x^{2}-0.0022 x+0.617$. Prob $>F<0.001$.

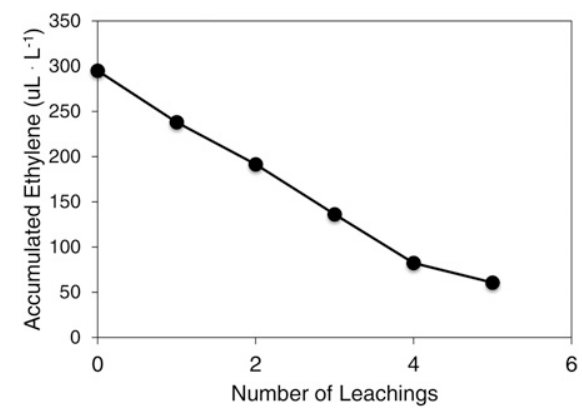

Fig. 6. Accumulation (from off-gassing) of ethylene remaining in ethephon treated soilless substrate previously leached with 100 to $500 \mathrm{~mL}$ water (in 100-ml fractions). After leaching, the pots with media were placed into 1.9-L sealed containers, and ethylene was sampled after $24 \mathrm{~h}$ at room temperature. Symbols are means of four replicates, and most standard errors fall within the dimensions of the symbols used in the graph.

ethephon in reducing growth; these are areas for future work. Even in the absence of a clear explanation, it is expected that commercial growers will be able to adjust ethephon application rates as needed to fit with their individual production protocols.

When a growth regulator is applied in the root zone, it is expected that it must be absorbed into the roots and move upward in the plant before it exerts its effect. In the case of ethephon, root absorption and translocation is not the only means of exerting an effect. It is conceivable that ethylene emanation within the soil profile could exert a direct effect, considering the Narcissus intercalary meristem where leaf cell division and elongation mainly occur (Denne, 1960), are, in normal Narcissus culture, under the surface of the potting substrate. Whether this is a mechanism explaining growth effects of root-zone ethephon in Narcissus is presently unclear.

Although research on ethephon translocation in phloem is limited, the majority of published work suggests that ethephon is at least moderately mobile when applied to source leaves. In tomato and cherries, labeled ethephon was readily translocated from source leaves to developing fruit and other sinks (Edgerton and Hatch, 1972; Yamaguchi et al., 1971). Weaver et al. (1972) showed that radioactivity accumulated in grape shoot tips after application of ${ }^{14} \mathrm{C}$-ethephon to mature leaves. Foster et al. (1992) demonstrated ethylene emanation from developing spikes (sinks) when ethephon was applied to barley flag (source) leaves. On the other hand, Young and Jahn (1975), working with a citrus system, found very little to no movement of labeled ethephon from leaves or fruit.

Even less is known about the extent of root absorption and xylem transport of ethephon in intact plants. Kwong and Lagerstedt (1977) showed root-zone-applied ethephon caused abscission of trifoliate leaves and stem terminals in bean, suggesting root absorption and upward movement, presumably in the xylem. Ethephon applied to root zones of easter lily (Lilium longiflorum) when plants were 5-20 cm tall caused substantial levels of flower abortion, suggesting ethylene injury (W.B. Miller, unpublished data). Since untreated plants in the experiment showed no injury and were randomized in close proximity with ethephontreated plants, it seems likely that the observed flower abortion was not due to a general offgassing of ethylene from the root zones of treated plants. Instead, it suggests ethephon was absorbed and moved upward in the plant, where it decomposed to ethylene and caused flower abortion.

It is axiomatic to apply PGRs (especially antigibberellin chemicals) early in the crop cycle so as to reduce future stem or leaf elongation. For example, Gilbertz (1992) showed that earlier sprays of two antigibberellin synthesis PGRs had greater effect on chrysanthemum compared with applications later in the crop. With poinsettia, Niu et al. (2001) showed reduced efficacy of paclobutrazol substrate drenches when applied later in the crop cycle. Such an effect does not appear to exist with Narcissus and ethephon substrate drenches. In the present work, Narcissus plant size at the time of root-zone ethephon application had no effect on final plant size (Figs. 1 and 2). Although the reasons for this are unclear, it is possible to speculate. Assuming ethephon is absorbed by roots and translocated in the xylem, it would be absorbed more quickly by the larger Narcissus plants (more leaves, more transpiration, and therefore increased ethephon uptake). By the time smaller plants grow and develop additional transpiring leaf area, much of the ethephon applied may have been leached away (Fig. 5) or off-gassed as ethylene (Fig. 6). Alternatively, perhaps sensitivity to ethylene increases as Narcissus plants grow, such that a given dose on a larger plant has a more powerful and immediate effect on the remaining growth potential of the stems and leaves. Under such a scenario, younger leaves and stem would be less sensitive at the moment of application (but have a longer 
future growing period for the ethephon to exert its effect). Simultaneously, ethylene and/or ethephon levels in the root zone dissipate in the days following application such that as plants enter into a more ethyleneresponsive phase, there is less ethylene present. Additional work will be needed to explain this intriguing observation.

Even in the absence of a clear mechanism describing how root-zone ethephon is inhibiting Narcissus growth, our findings are still useful for growers. Narcissus plants respond to the ethephon dose delivered to the root zone, and the ethephon may be delivered in a relatively large range of volumes used in the industry. Plants are responsive to root-zone ethephon in a range of commonly used growing temperatures, and the date of application of the ethephon can be flexible, from soon after bringing plants into the greenhouse to shortly before flowering. The experiments presented here significantly expand on the initial observations that ethephon substrate drenches could be a useful technique for height control of potted Narcissus plants (Miller et al., 2012).

\section{Literature Cited}

De Hertogh, A. 1996. Potted daffodils (Narcissus), p. B69-83. In: The Holland Bulb Forcer's Guide. 5th ed. Intl. Flower Bulb Ctr., Hillegom, The Netherlands.

Denne, M.P. 1960. Leaf development in Narcissus pseudonarcissus L. II. The comparative development of scale and foliage leaves. Ann. Bot. (Lond.) 24:32-47.

Edgerton, L.J. and A.H. Hatch. 1972. Absorption and metabolism of $14 \mathrm{C}(2$-chloroethyl)phosphonic acid in apples and cherries. J. Amer. Soc. Hort. Sci. 97:112-115.

Flore, J.A. and M.J. Bukovac. 1982. Factors influencing absorption of $14 \mathrm{C}$ (2-chloroethyl)phosphonic acid by leaves of cherry. J. Amer. Soc. Hort. Sci. 107:965-968.

Foster, K.R., D.M. Reid, and R.P. Pharis. 1992 Ethylene biosynthesis and ethephon metabolism and transport in barley. Crop Sci. 32:1345-1352.

Gilbertz, D.A. 1992. Chrysanthemum response to timing of paclobutrazol and uniconazole. HortScience 27:322-323.

Kwong, F.Y. and H.B. Lagerstedt. 1977. Translocation of ethephon in beans and peas. J. Amer. Soc. Hort. Sci. 102:437-440.

Lougheed, E.C. and E.W. Franklin. 1972. Effects of temperature on ethylene evolution from ethephon. Can. J. Plant Sci. 52:769-773.
Miller, W.B., N.S. Mattson, X. Xie, D. Xu, C.J. Currey, K.L. Clemens, R.G. Lopez, M. Olrich, and E.S. Runkle. 2012. Ethephon substrate drenches inhibit stem extension of floriculture crops. HortScience 47:1312-1319.

Moe, R. 1980. The use of ethephon for control of plant height in daffodils and tulips. Acta Hort. 109:197-204.

Niu, G., R. Heins, and W. Carlson. 2001. Height control of Euphorbia pulcherrima 'Freedom' using paclobutrazol drenches. HortScience 36:575.

Olien, W.C. and M.J. Bukovac. 1978. Effect of temperature on rate of ethylene evolution from ethephon and from ethephon-treated leaves of sour cherry. J. Amer. Soc. Hort. Sci. 103: 199-202.

Weaver, R.J., H.A. Abdel-Gawad, and G.C. Martin. 1972. Translocation and persistence of $1,2-{ }^{14} \mathrm{C}$-(2-chloroethyl)-phosphonic acid (ethephon) in Thompson seedless grapes. Physiol. Plant. 26:13-16.

Yamaguchi, M., C.W. Chi, and S.F. Yang. 1971. The fate of ${ }^{14} \mathrm{C}(2$-chloroethyl)phosphonic acid in summer squash, cucumber, and tomato. J. Amer. Soc. Hort. Sci. 96:606-609.

Young, R.H. and O. Jahn. 1975. The fate of $1,2-{ }^{14} \mathrm{C}-(2$-chloroethyl)phosphonic acid in citrus. J. Amer. Soc. Hort. Sci. 100:496-499. 